\title{
THE CHANGE OF SANDY SOIL PROPERTIES AFTER ADDING CHARCOAL PRODUCED FROM A TRADITIONAL KILN IN THE MEKONG DELTA, VIET NAM
}

\author{
Huynh Phan Khanh Binh ${ }^{1}$, Nguyen Van Tho ${ }^{2}$, Tran My Vien ${ }^{3}$
}

\begin{abstract}
This study aimed to use charcoal derived from the bamboo and melaleuca produced by traditional kiln applied to sandy soil growing mustard green (Brassica juncea L.). The charcoals were applied at three ratio $(1 \%$, $2 \%$, and $3 \%$, which correspond to 10,20 , and $30 \mathrm{~g}$ charcoal/kg soil in pots) and the control treatment without charcoal. Soil properties were investigated including bulk density, $\mathrm{pH}$, electrical conductivity $(E C)$, cation exchange capacity $(C E C)$, organic matter content, total nitrogen, and total phosphorous. The results showed that bulk density decreased in charcoal-treated soils. $\mathrm{pH}$ and $\mathrm{EC}$ were in the suitable range for plants. Nutrients and CEC of the soil in the charcoal treatment were significantly higher compared with the control (CEC increase 6.8\% to 16\%; TC increase $80 \%$ to $115 \%$; TN increase 37.5 to $75 \%$ ). Green mustard growing on charcoalamended soil had greater height (higher 3\% to $21 \%$ ), bigger leaves, and higher yield (increase $18 \%$ to $81 \%$ ) than those of plants groomed in the control treatment. This study showed the potential of using charcoal as supplying nutrient to the poor soil. Moreover, the abundant of raw material and easy to produce, it is suitable for applying in the Mekong Delta, Viet Nam, and other countries with similar conditions and infrastructure.
\end{abstract}

Keywords: biochar, charcoal, soil amendment.

\section{INTRODUCTION}

In recent years, the application of biochar as soil amendment has received a lot of attention

\footnotetext{
${ }^{1,2}$ Mien Tay Construction University

${ }^{3}$ Can Tho University

Email: huynhphankhanhbinh@mtu.edu.vn

Received date: $14^{\text {th }}$ October 2020; Revised date: $24^{\text {th }}$ November 2020; Accepted date: $25^{t h}$ December 2020
}

around the world. Many studies have investigated the impacts of biochar on $\mathrm{C}$ sequestration [1], [2], crop production [3], [4], greenhouse gas emission [5], [6], remediation of contaminated soils [7], [8], etc. The potential of biochar on soil amendment is not doubted leading to the necessity of producing a large of amount biochar for agriculture and remediation of contaminated soil. The principle of biochar production is pyrolysis biomass in limited oxygen condition [9], equivalent to produce charcoal in the traditional commercial kiln. However, charcoal produced from traditional technique was not widely recognized in the soil amendment ability, studies investigated the effect of charcoal in soil are still lacking. Meanwhile, charcoal production is widespread in the Mekong delta, Viet Nam, focus mainly on two provinces: Hau Giang and Soc Trang. The main feedstock for production is wood from fruit gardens that do not exploit anymore. More than 1,500 traditional kilns in these two provinces, could be the great woody charcoal source for amendment and remediation of contaminated soil in agriculture and other applications in the environment, especially in the developing countries due to the low cost and easy production.

On the other hand, the quality of agricultural land in Viet Nam tends to decrease due to desertification or the abuse of fertilizers and plant protection from drugs that reduce the productivity of the soil. Typically, soil in the hills, or soil with over fertility in the Mekong Delta, this affects agricultural cultivation. There are many researches on biochar applications to improve soil condition and soil productivity in Viet Nam and the world. However, studies have just shown the effects of different biochars at different soil types [3].

Therefore, the aim of this study is to determine the effects of woody charcoal derived from 
Bamboo and Melaleuca produced by the traditional kiln on the properties of the soil, and the plant growth, specifically on mustard green. The results are expected to contribute in promoting the use of those charcoals as soil amendments instead of using the artificial fertilizers.

\section{MATERIALS AND METHODS}

\section{A. Preparation of charcoals}

The bamboo (Bambusa bambos (L.) Voss) and melaleuca (Melaleuca cajuputi Powell) were collected in Chau Thanh District, Hau Giang Province, Viet Nam. The raw material was cut with a length of 50-60 cm, especially, melaleuca need to peel before pyrolysis.

Thereafter, bamboo and melaleuca were put inside the charcoal kiln of a farmer at Phu Tan charcoal production village, Chau Thanh District, Hau Giang Province, Viet Nam (Figure 1). The time of pyrolysis was 25 days and the highest temperature in the kiln was $284^{\circ} \mathrm{C}$ on the $17^{\text {th }}$ day [10].

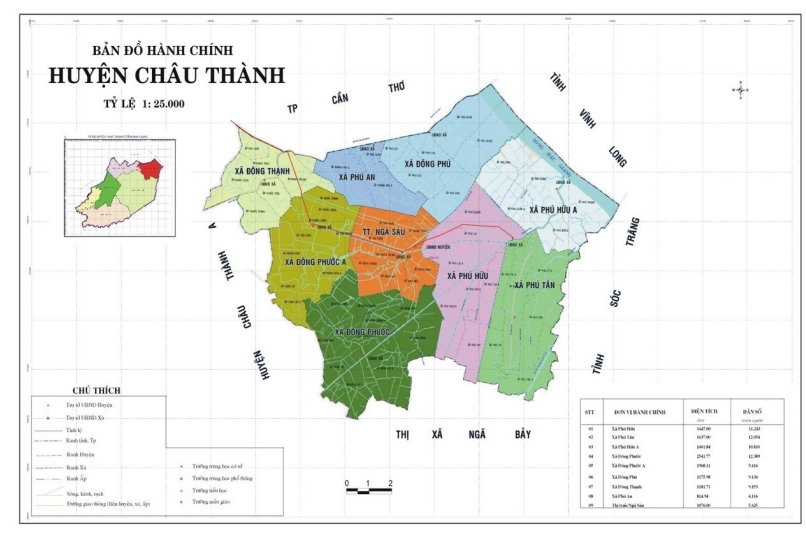

Fig. 1: The charcoal production village

\section{B. Experimental design}

A pot experiment was designed for evaluating the effect of two kinds of charcoal on sandy soil and the growth of mustard green (Brassica juncea L.) in the pots. There were four seeds/pot, the diameter of the pot is $20 \mathrm{~cm}$.

The experiment was designed in a net house at Can Tho University, Can Tho City, Viet Nam with the Randomized complete block design
(RCBD) two factors: kind of charcoals (Bamboo charcoal - BC and Melaleuca charcoal - MC) and application rates $(1 \%, 2 \%$, and $3 \%)$, and a treatment without charcoal which acted as control treatment used for comparing with charcoaltreats. Each treatment was replicated four times, thus the experiment included seven treatments and twenty-eight pots in the experiment. The treatments in the experiment were described in Table 1.

Table 1. Summary of treatments

\begin{tabular}{lcc}
\hline Charcoal & $\begin{array}{c}\text { Application } \\
\text { rates }\end{array}$ & Treatments \\
\hline No charcoal & - & Control \\
Melaleuca charcoal & $1 \%$ & $\mathrm{MC} 1 \%$ \\
Melaleuca charcoal & $2 \%$ & $\mathrm{MC} 2 \%$ \\
Melaleuca charcoal & $3 \%$ & $\mathrm{MC} 3 \%$ \\
Bamboo charcoal & $1 \%$ & $\mathrm{BC} 1 \%$ \\
Bamboo charcoal & $2 \%$ & $\mathrm{BC} 2 \%$ \\
Bamboo charcoal & $3 \%$ & $\mathrm{BC} 3 \%$ \\
\hline
\end{tabular}

The charcoal after sieving to $2 \mathrm{~mm}$ was mixed into sandy soil before filling into the pots, there was $5 \mathrm{~kg}$ of sandy soil in each pot, so the amount of charcoal was $50 \mathrm{~g}, 100 \mathrm{~g}$, and $150 \mathrm{~g}$ for $1 \%$, $2 \%$, and $3 \%$ application rates, respectively. The Mustard green (Brassica juncea L.) was planted following the guide of Phu Nong company, which was presented on the seed's package.

The soil samples were collected two times, before planting and after harvesting for analyzing physical and chemical properties to monitor planted soil change if treated by charcoal. The parameters of the sandy soil were monitored including bulk density, $\mathrm{pH}$, EC, total nitrogen, total phosphorus, organic carbon, and CEC.

The agronomy data of mustard green were collected at the end of the cultivation process, including the plant height $(\mathrm{cm})$, leaf size $(\mathrm{cm})$, and crop yield (g/pot). 


\section{Statistic analysis}

One-way ANOVA was performed to assess the statistically significant differences in soil properties and agronomy parameters between treatments. LSD post-hoc test was used to determine the significant difference at the 0.05 level.

The $\mathrm{R}$ statistical programming language was used to analyze data and graphs.

\section{RESULTS AND DISCUSSION}

\section{A. The properties of charcoal}

Table 2 shows the charcoals having high particle density, $\mathrm{pH}$ value, electrical conductivity (EC), and ash content. At high temperatures, the structure of biomass was destroyed. According to Brewer [11], particle density of biochar range in $1.5-1.7 \mathrm{~g} / \mathrm{cm}^{3}$, there was a relation between particle density and ash content in charcoal. The high ash content was the result of a progressive concentration of minerals and destructive volatilization of cellulosic matter at high temperatures [12].

Table 2. Properties of charcoal in studies

\begin{tabular}{lcc}
\hline Parameter & $\begin{array}{r}\text { Bamboo } \\
\text { charcoal }\end{array}$ & $\begin{array}{r}\text { Melaleuca } \\
\text { charcoal }\end{array}$ \\
\hline $\begin{array}{l}\text { Particle density } \\
\left(\mathrm{g} / \mathrm{cm}^{3}\right)\end{array}$ & $1.41 \pm 0.05$ & $1.41 \pm 0.02$ \\
$\mathrm{pH}$ & $7.63 \pm 0.01$ & $6.97 \pm 0.04$ \\
$\mathrm{EC}(\mathrm{mS} / \mathrm{cm})$ & $6.85 \pm 0.04$ & $1.19 \pm 0.01$ \\
$\mathrm{Ash}$ content $(\%)$ & $23.96 \pm 0.32$ & $7.67 \pm 4.55$ \\
$\mathrm{~N}(\%)$ & $0.61 \pm 0.03$ & $0.30 \pm 0.00$ \\
$\mathrm{P}(\%)$ & $0.36 \pm 0.01$ & $0.19 \pm 0.00$ \\
$\mathrm{~K}(\%)$ & $1.10 \pm 0.11$ & $0.29 \pm 0.01$ \\
$\mathrm{Ca}(\%)$ & $0.04 \pm 0.00$ & $0.19 \pm 0.04$ \\
$\mathrm{Mg}(\%)$ & $0.15 \pm 0.02$ & $0.13 \pm 0.01$ \\
$\mathrm{Si}(\%)$ & $5.79 \pm 0.05$ & $1.30 \pm 0.01$ \\
\hline
\end{tabular}

(Note: Presented value: mean \pm standard deviation)
The $\mathrm{pH}$ value of charcoal increased due to the evaporation of acidity function group $(-\mathrm{COOH}$, $\mathrm{OH})$ in the pyrolysis process. On the other hand, the compounds of $\mathrm{CO}_{3^{2-}}\left(\mathrm{CaCO}_{3}, \mathrm{MgCO}_{3}\right)$ and alkalinity elements $(\mathrm{Na}, \mathrm{K})$ were durable in the pyrolysis process [13]. EC value in bamboo charcoal was high $(6.85 \pm 0.04 \mathrm{mS} / \mathrm{cm})$ but it could not cause problems to plants when mixed with soil [14], because the amount of charcoal added to the soil is not enough for the salinity problem to plants (base on charcoal/soil weight).

\section{B. Effect of charcoal on sandy soil properties}

The application of charcoal has improved the bulk density, chemical properties, and nutrient retention of sandy soil as presented in Figure 2, Table 3, and Table 4.

The bulk density increased at the control treatment $\left(1.29 \pm 0.01 \mathrm{~g} / \mathrm{cm}^{3}\right.$ and $1.46 \pm 0.02$ $\mathrm{g} / \mathrm{cm}^{3}$ before cultivating and after harvesting, respectively) but decreased at all charcoal-treated treatments. The difference was significant statistically $(\mathrm{p}<0.05)$. The soil bulk density was decreased while increased the application rate of charcoal (Figure 2). Bulk density of soil in the charcoal-treatment was increased after harvesting to compare with the one before cultivating, but the difference was not significant $(p>0.05)$. Adding charcoal to soil reduced the compression, provided more space for plant roots, microorganisms, and oxygen for the synthesizing of organic matter in the soil. These results were consistent with other soil-biochar incubation studies [1]-[4].

The improvement of the soil bulk density has enhaced chemical parameters (Table 3). In general, the chemical properties of soil with charcoal-treatment were significantly increased to compare with the chemical properties of control treatment $(\mathrm{p}<0.05)$. The $\mathrm{pH}$ value of soil in charcoal-treatment was higher than that of the soil without charcoal. The melaleuca charcoal was more effective than bamboo charcoal in increasing the $\mathrm{pH}$ value of soil whereas the most effective application rate of these two kinds of charcoal was presented at $2 \%$. The $\mathrm{pH}$ value in charcoal-treatment increased after cultivating that caused charcoal dissolving ash and releasing 


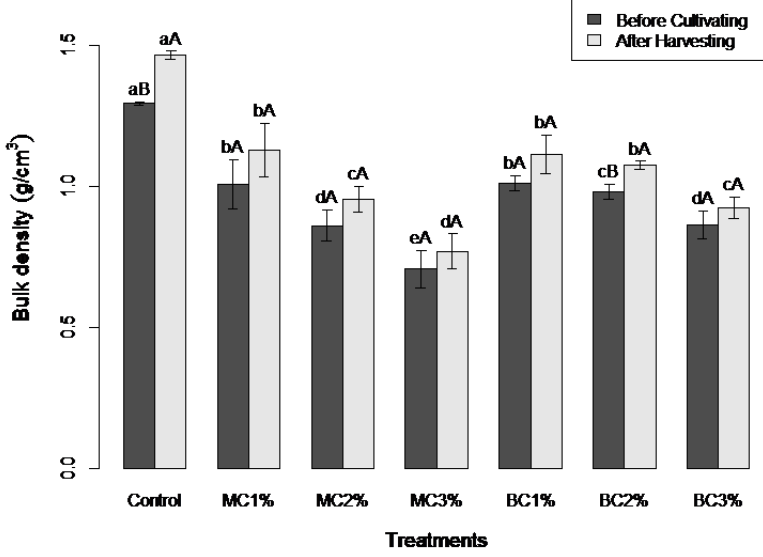

Fig. 2: Effect of charcoal on soil bulk density

(Note: The columns with the same letters followed ( $a, b, c, A, B, C)$ were no significant difference statistically at $p<0.05$.)

alkaline cations $\left(\mathrm{Ca}^{2+}, \mathrm{Mg}^{2+}\right.$, and $\left.\mathrm{K}^{+}\right)$into soil colloids [15], [16].

Electrical conductivity (EC) is using to measure salt amount in the soil. It is an important indicator of soil health with direct effect on crop yields, crop suitability, and activity of soil microorganisms. The EC ranged from $0.05 \mathrm{mS} / \mathrm{cm}$ to $0.09 \mathrm{mS} / \mathrm{cm}$. EC in all treatments was stable and in the appropriate range for plant growth. These $\mathrm{pH}$ and EC of soil were consistent with other previous studies [9], [12].

For the CEC value, melaleuca charcoal was also shown more effective in soil amendment than bamboo charcoal (Table 3). The highest value of CEC was found at MC3\% (5.85 \pm 0.19 $\mathrm{cmol} / \mathrm{kg}$ ) and the lowest was found at the control $(5.05 \pm 0.16 \mathrm{cmol} / \mathrm{kg})$. However, there was no significant difference to compare with the CEC value in the control treatment at the ratio of $1 \%$ adding two kinds of charcoal. The charcoal application rate has a positive linear correlation with the CEC of soil. This CEC result was in line with the previous studies [17], [18].

The nutrient parameters of sandy soil after harvesting were shown in Table 4. In general, the nutrient parameters in adding charcoal treatment were increased to compare with the control treatment (without charcoal). Total organic (Total C) in charcoal-treatment was higher than the total
Table 3. Effect of charcoal on soil chemical properties after harvesting

\begin{tabular}{lcrrr}
\hline Treatments & $\mathbf{p H}$ & $\begin{array}{r}\mathbf{E C} \\
(\mathrm{mS} / \mathrm{cm})\end{array}$ & $\begin{array}{r}\text { CEC } \\
(\mathrm{cmol} / \mathrm{kg})\end{array}$ \\
\hline Control & $5.73 \pm 0.09^{\mathrm{f}}$ & $0.08 \pm 0.00^{\mathrm{b}}$ & $5.05 \pm 0.16^{\mathrm{d}}$ \\
\hline $\mathrm{MC} 1 \%$ & $6.45 \pm 0.01^{\mathrm{b}}$ & $0.06 \pm 0.00^{\mathrm{c}}$ & $5.29 \pm 0.23^{\mathrm{cd}}$ \\
\hline $\mathrm{MC} 2 \%$ & $6.65 \pm 0.02^{\mathrm{a}}$ & $0.05 \pm 0.00^{\mathrm{d}}$ & $5.57 \pm 0.10^{\mathrm{abc}}$ \\
\hline $\mathrm{MC} 3 \%$ & $6.36 \pm 0.01^{\mathrm{c}}$ & $0.05 \pm 0.00^{\mathrm{d}}$ & $5.85 \pm 0.19^{\mathrm{a}}$ \\
\hline $\mathrm{BC} 1 \%$ & $6.12 \pm 0.02^{\mathrm{e}}$ & $0.09 \pm 0.00^{\mathrm{a}}$ & $5.34 \pm 0.23^{\mathrm{cd}}$ \\
\hline $\mathrm{BC} 2 \%$ & $6.21 \pm 0.06^{\mathrm{d}}$ & $0.06 \pm 0.00^{\mathrm{c}}$ & $5.45 \pm 0.18^{\mathrm{bc}}$ \\
\hline $\mathrm{BC} 3 \%$ & $6.15 \pm 0.01^{\mathrm{de}}$ & $0.06 \pm 0.00^{\mathrm{c}}$ & $5.78 \pm 0.22^{\mathrm{ab}}$ \\
\hline
\end{tabular}

(Note: In the same column, the values with the same letters followed $(a, b, c \ldots)$ are no significant difference statistically at $p<0.05 . N=4$.)

$\mathrm{C}$ in the control treatment(without charcoal), the difference was from $80 \%$ to $115 \%$. Melaleuca charcoal-treatment (MC) has higher total carbon than bamboo charcoal-treatment (BC), the highest was at treatment $\mathrm{MC} 3 \%(1.40 \% \pm 0.00)$, the next one is at $\mathrm{BC} 3 \%(1.33 \% \pm 0.00)$ and treatment $\mathrm{BC} 1 \%$ - the lowest total carbon content among charcoal-treated $(1.17 \% \pm 0.08)$. The application with different ratios has a positive correlation with the total carbon content in the soil.

Similar results were found in total nitrogen and total phosphorus content in the soil after harvesting. Bamboo charcoal has not shown the difference among all three application rates for total nitrogen and total phosphorus ( $p>0.05)$. Adding charcoal into the soil retains nutrients from fertilizer, leading to the nutrient in charcoal treatment was higher than that of the control (without charcoal).

Many previous studies had found that adding charcoal into soil helped to improve crop productivity by enhancing soil properties [19]-[21]. Besides, with high CEC [22], charcoal retained nutrient ions, reduced nutrient leaching in soil [23], improved soil fertility. The charcoal has also improved the physical properties of soil, observed by the improving soil bulk density [17], [24]. 
Table 4. Effect of charcoal on soil chemical properties after harvesting

\begin{tabular}{lcccc}
\hline Treatments & $\begin{array}{c}\text { Total C } \\
(\%)\end{array}$ & $\begin{array}{c}\text { Total N } \\
(\%)\end{array}$ & $\begin{array}{c}\text { Total P } \\
(\%)\end{array}$ \\
\hline Control & $0.65 \pm 0.02^{\mathrm{e}}$ & $0.08 \pm 0.01^{\mathrm{c}}$ & $0.01 \pm 0.00^{\mathrm{c}}$ \\
\hline $\mathrm{MC} 1 \%$ & $1.24 \pm 0.03^{\mathrm{cd}}$ & $0.12 \pm 0.00^{\mathrm{b}}$ & $0.02 \pm 0.00^{\mathrm{a}}$ \\
\hline $\mathrm{MC} 2 \%$ & $1.31 \pm 0.04^{\mathrm{b}}$ & $0.14 \pm 0.01^{\mathrm{a}}$ & $0.01 \pm 0.00^{\mathrm{b}}$ \\
\hline $\mathrm{MC} 3 \%$ & $1.40 \pm 0.00^{\mathrm{a}}$ & $0.12 \pm 0.00^{\mathrm{b}}$ & $0.02 \pm 0.00^{\mathrm{a}}$ \\
\hline $\mathrm{BC} 1 \%$ & $1.17 \pm 0.08^{\mathrm{d}}$ & $0.11 \pm 0.01^{\mathrm{b}}$ & $0.01 \pm 0.00^{\mathrm{b}}$ \\
\hline $\mathrm{BC} 2 \%$ & $1.22 \pm 0.03^{\mathrm{d}}$ & $0.11 \pm 0.00^{\mathrm{b}}$ & $0.01 \pm 0.00^{\mathrm{b}}$ \\
\hline $\mathrm{BC} 3 \%$ & $1.33 \pm 0.00^{\mathrm{b}}$ & $0.11 \pm 0.01^{\mathrm{b}}$ & $0.01 \pm 0.00^{\mathrm{b}}$ \\
\hline
\end{tabular}

(Note: In the same column, the values with the same letters followed $(a, b, c \ldots)$ are no significant difference statistically at $p<0.05 . N=4$.)

\section{Effect of charcoal on the growth of Brassica juncea $L$.}

The plant height was found highest in treatment $\mathrm{MC} 3 \%$ and $\mathrm{BC} 3 \%$, followed by $\mathrm{MC} 2 \%$ and $\mathrm{BC} 2 \%$. There was no significant difference between $\mathrm{MC} 1 \%, \mathrm{BC} 1 \%$ to compare with the one in the control treatment (Table 5).

Table 5. Effect of charcoal on the growth of Brassica juncea $\mathrm{L}$.

\begin{tabular}{lccc}
\hline Treatments & $\begin{array}{c}\text { Plant } \\
\text { height (cm) }\end{array}$ & $\begin{array}{c}\text { Leaves } \\
\text { length (cm) }\end{array}$ & $\begin{array}{c}\text { Leaves } \\
\text { width (cm) }\end{array}$ \\
\hline Control & $19.75 \pm 1.39^{\mathrm{d}}$ & $16.26 \pm 0.80^{\mathrm{b}}$ & $5.56 \pm 0.55^{\mathrm{c}}$ \\
\hline $\mathrm{MC} 1 \%$ & $20.34 \pm 1.59^{\mathrm{cd}}$ & $16.37 \pm 0.97^{\mathrm{b}}$ & $6.30 \pm 0.28^{\mathrm{b}}$ \\
\hline $\mathrm{MC} 2 \%$ & $21.77 \pm 0.73^{\mathrm{bc}}$ & $16.48 \pm 0.86^{\mathrm{b}}$ & $6.58 \pm 0.41^{\mathrm{b}}$ \\
\hline $\mathrm{MC} 3 \%$ & $23.99 \pm 1.19^{\mathrm{a}}$ & $19.93 \pm 1.52^{\mathrm{a}}$ & $7.40 \pm 0.22^{\mathrm{a}}$ \\
\hline $\mathrm{BC} 1 \%$ & $20.81 \pm 1.32^{\mathrm{cd}}$ & $16.09 \pm 1.80^{\mathrm{b}}$ & $6.13 \pm 0.54^{\mathrm{bc}}$ \\
\hline $\mathrm{BC} 2 \%$ & $21.77 \pm 0.63^{\mathrm{bc}}$ & $16.12 \pm 1.71^{\mathrm{b}}$ & $6.53 \pm 0.43^{\mathrm{c}}$ \\
\hline $\mathrm{BC} 3 \%$ & $23.34 \pm 0.71^{\mathrm{ab}}$ & $18.46 \pm 0.41^{\mathrm{a}}$ & $6.72 \pm 0.48^{\mathrm{b}}$ \\
\hline
\end{tabular}

(Note: In the same column, the values with the same letters followed $(a, b, c)$ are no significant difference statistically at $p<0.05$ )
The growth of the leaves' Brassica juncea L. size was correlated with the charcoal application rates in this study. The leaves growth parameter showed the development ability of the plant, because the leaf plays an important role in the nutrient synthesis, creating biomass for plants, thereby deciding harvest yield. The results of this study showed that the treatments with adding charcoal gave better leaf size (include length, width) than those without charcoal. The plant height and leaf size proved that adding charcoal to the soil improved the soil's porosity, changed $\mathrm{pH}$, and retains the nutrients provided from the fertilizer, the plants can absorb more nutrients, lead to the crop yield better.

The crop yield (g/pot) of Brassica juncea L. was showed in Figure 3. The highest yield was recorded at the MC3\% treatment. All treatments with melaleuca charcoal were higher crop yield than bamboo charcoal. There was no significant difference between the $1 \%$ and $2 \%$ application rates of both two charcoal. The crop yield of Brassica juncea L. was increased under all application rates for two kinds of charcoal from $18 \%$ to $81 \%$ compared with the crop yield of the control treatment.

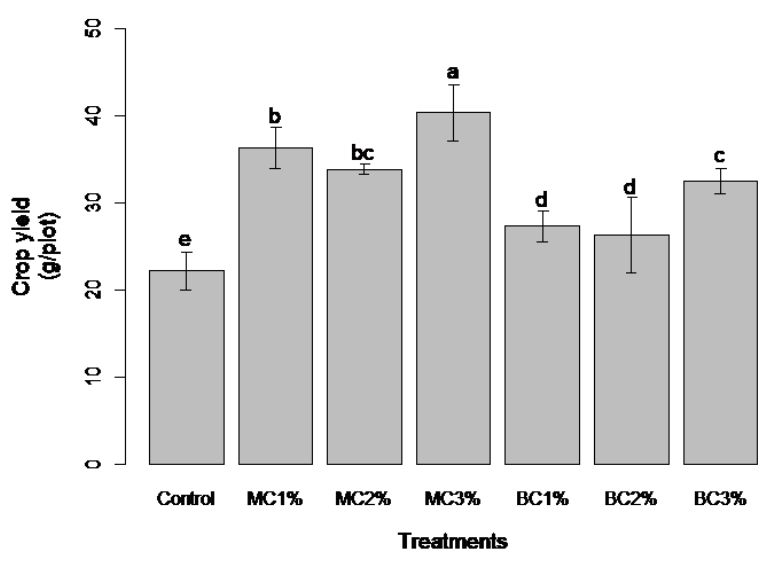

Fig. 3: Effect of charcoal on soil chemical properties after harvesting

(Note: In the same column, the values with the same letters followed $(a, b, c \ldots)$ are no significant difference statistically at $p<0.05 . N=4$.) 
The increase of crop yield corresponds to the amount of charcoal adding to the soil, because charcoal increases the soil porosity [25], creates more pores in the soil, is favorable for the development of roots and helps plants to grow well.

In general, the results showed that adding charcoal to the soil helps plants better in growing, gave higher yields, and especially the yield of the charcoal-treatment was the highest. The results proved that the role of biochar (charcoal) in increasing soil porosity, facilitating plant root development. In addition, it enhanced nutrients in the root zone, reduce nutrient leaching [29], thereby providing adequate nutrition for the plants to grow.

\section{CONCLUSIONS}

Charcoal derived from traditional kiln could be applied widely, especially in environment, agriculture. Adding charcoal into the soil improves chemical and physical properties, as well as decreases the compress, increases organic matter and nutrients in the soil, supports the mineralization process, and improves the cation exchange capacity in the soil.

It could be concluded that the benefit of adding charcoal into the soil is dependent on the kind and the application rate of charcoal. Although these results are good on soil fertility and plant growth, further studies with longer period, with different plants are needed to conduct to affirm the benefits of charcoal for amending soil.

\section{REFERENCES}

[1] Xu Zhao, Jiangwei Wang, Shenqiang Wang, Guangxi Xing. Successive straw biochar application as a strategy to sequester carbon and improve fertility: A pot experiment with two rice/wheat rotations in paddy soil. Plant Soil. 2014; 378:279-294.

[2] Balal Yousaf, Guijian Liu, Ruwei Wang, Qumber Abbas, Muhammad Imtiaz, Ruijia Liu. Investigating the biochar effects on C-mineralization and sequestration of carbon in soil compared with conventional amendments using the stable isotope $(\delta 13 \mathrm{C})$ approach. $G C B$ Bioenergy. 2017; 9(6):1085-1099.

[3] David Nathaniel Mulcahy, David Linda Mulcahy, Dennis Dietz. Biochar soil amendment increases tomato seedling resistance to drought in sandy soils. Journal of Arid Environments. 2013; 88:222-225.
[4] Kingsley Chinyere Uzoma, Mitsuhiro Inoue, Andry Heninstoa, Haruyuki Fujimaki, Zahoor Ahmad, Eiji Nishihara. Effect of cow manure biochar on maize productivity under sandy soil condition. Soil Use and Management. 2011; 27(2):205-212.

[5] Terry J. Rose, Brad Keen, Stephen G. Morris, Peter Quin, Josh Rust, Lee Kearney et al. Application of woody biochar and woody mulch to mitigate nitrous oxide emissions from a poultry litter-amended soil in the subtropics. Agriculture Ecosystems and Environment. 2016; 228:1-8.

[6] Youzhi Feng, Yanping Xu, Yongchang Yu, Zubin Xie, Xiangui Lin. Mechanisms of biochar decreasing methane emission from Chinese paddy soils. Soil Biology and Biochemistry. 2012; 46:80-88.

[7] Tom Sizmur, Richard Quilliam, Aline Peregrina Puga, Eduardo Moreno-Jiménez, Luke Beesley, Jose L. Gomez-Eyles. Application of Biochar for Soil Remediation. SSSA Special Publication. 2015; 63:30.

[8] Anushka Upamali, Season S. Chen, Daniel C. W. Tsang, Ming Zhang, Meththika Vithanage, Sanchita Mandal et al. Engineered/designer biochar for contaminant removal / immobilization from soil and water: Potential and implication of biochar modification. Chemosphere. 2016; 148:276-291.

[9] Leigh D. Burrell, Franz Zehetner, Nicola Rampazzo, Bernhard Wimmer, Gerhard Soja. Long-term effects of biochar on soil physical properties. Geoderma. 2016; 282:96-102.

[10] Nguyen Ngoc Truyen, Tran Duc Thanh, Nguyen Huu Chiem, Do Thi My Phuong, Nguyen Xuan Loc. A survey of charcoal production at Phu Tan village, Chau Thanh district, Hau Giang province. In Conference of Silvicultural and Climate change in Mekong Delta 2018. 2018:20-30.

[11] Catherine Elizabeth Brewer. Biochar characterization and engineering [Thesis]. Iowa State University. 2012.

[12] Xinde Cao, Willie Harris. Properties of dairymanure-derived biochar pertinent to its potential use in remediation. Bioresource Technology. 2010; 101(14):5222-5228.

[13] Jin-Hua Yuan, Ren-Kou Xu, Hong Zhang. The forms of alkalis in the biochar produced from crop residues at different temperatures. Bioresource Technology. 2011; 102(3): 3488-3497.

[14] Suzanne E. Allaire, S. F. Lange, Isabelle K. Auclair, Melissa Quinche, L. Greffard. Analyses of biochar properties. Centre de Recherche sur les Matériaux renouvelables. 2015. DOI: 10.13140/RG.2.1.2789.4241.

[15] Christoph Steiner, Wenceslau G. Teixeira, Johannes Lehmann, Thomas Nehls, Jeferson Luis Vasconcelos de Macedo, Winfried E. H. Blum et al. Long term effects of manure, charcoal and mineral fertilization on crop production and fertility on a highly weathered Central Amazonian upland soil. Plant and Soil. 2007; 291: 275-290.

[16] Charles A. Mullen, Akwasi A. Boateng, Neil M. Goldberg, Isabel M. Lima, David A. Laird, Kevin 
B. Hicks. Bio-oil and bio-char production from corn cobs and stover by fast pyrolysis. Biomass and Bioenergy. 2010; 34(1):67-74.

[17] D. N. Vidana Gamage, R. B. Mapa, R. S. Dharmakeerthi, A. Biswas. Effect of rice-husk biochar on selected soil properties in tropical Alfisols. Soil Research. 2016; 54(3):302-310.

[18] L. Van Zwieten, S. Kimber, S. Morris, K. Y. Chan, A. Downie, J. Rust, S. Joseph et al. Effects of biochar from slow pyrolysis of papermill waste on agronomic performance and soil fertility. Plant and Soil. 2010; 327:235-246.

[19] Anand Mishra, Koungveng Taing, Michael W. Hall, Yoshiyuki Shinogi. Effects of Rice Husk and Rice Husk Charcoal on Soil Physicochemical Properties, Rice Growth and Yield. Agricultural Sciences. 2017; 8(9):1014-1032.

[20] Philip G. Oguntunde, Babatunde J. Abiodun, Ayodele E. Ajayi, Nick Van De Giesen. Effects of charcoal production on soil physical properties in Ghana. Journal of Plant Nutrition and Soil Science. 2008; 171(4):591-596.

[21] Dilek Angın, Sevgi Şensöz. Effect of Pyrolysis Temperature on Chemical and Surface Properties of Biochar of Rapeseed ( Brassica napus L.). International Journal of Phytoremediation. 2014; 16(7-8):684-693.

[22] Waled Suliman, James B. Harsh, Nehal I. Abu-Lail, Ann-Marie Fortuna, Ian Dallmeyer, Manuel GarciaPerez. Influence of feedstock source and pyrolysis temperature on biochar bulk and surface properties. Biomass and Bioenergy. 2016; 84:37-48.

[23] Allah Wadhayo Gandahi, Shah Faisal Baloch, Mohamad Saleem Sarki, Rabail Gandahi, Muhammad Siddique Lashari. Impact of rice husk biochar and macronutrient fertilizer on fodder maize and soil properties. International Journal of Biosciences. 2015; 7(4):12-21.
[24] Hong-Xia Chen, Zhang-Liu Du, Wei Guo, QingZhong Zhang. Effects of biochar amendment on cropland soil bulk density, cation exchange capacity, and particulate organic matter content in the North China Plain. Journal of Applied Ecology. 2011; 22(11):2930-4.

[25] Marcus Hardie, Brent Clothier, Sally Bound, Garth Oliver, Dugald Close. Does biochar influence soil physical properties and soil water availability?. Plant and Soil. 2014; 376:347-361.

[26] Vu Thang, Nguyen Hong Son. Research into biochar utilization for improvement of crop production ability of soil: Effects of different biochar types and aplication rate on rice growth and yield. Journal of Science Agricultural Technology Viet Nam. 2011; 3(24):1-5.

[27] Vu Duy Hoang, Nguyen Tat Canh, Nguyen Van Bien, Nhu Thi Hong Linh. Effect of Biochar and Foliar Fertilizer on Growth and Yield of Tomato Grown on Sandy Soil. Journal Science of Development. 2013; 11(5):603-613.

[28] Vu Duy Hoang, Nguyen Tat Canh, Nguyen Van Bien, Nhu Thi Hong Linh. Effect of Biochar and Foliar Fertilizer on Growth and Yield of Tomato Grown on Sandy Soil. Journal Science of Development. 2013; 11(5):603-613.

[29] David Laird, Pierce Fleming, Baiqun Wang, Robert Horton, Douglas Karlen. Biochar Impact on Nutrient Leaching from a Midwestern Agricultural Soil. Geoderma. 2010; 158:436-442. 